\title{
Paolo Gherri, Introduzione al diritto amministrativo canonico. Fondamenti, Giuffrè Editore, Milano 2015, ss. 318
}

\author{
DOI: http://dx.doi.org/10.15633/acan.1068
}

Studium kanonicznego prawa administracyjnego jest od zaledwie półwiecza przedmiotem szczególnego zainteresowania doktryny tak pod względem dogmatycznym, jak i praktycznego zastosowania. Mimo obiektywnych trudności - wynikających z braku teorii generalnej prawa kościelnego, jak i odrębnego traktatu kodeksowego De procedura administrativa - doktryna zdołała wypracować właściwe sobie stanowiska teoretyczno-metodologiczne, które w dalszym ciągu wymagają doskonalszej artykulacji technicznej i ekspozycyjnej, ze szczególnym uwzględnieniem fundamentów, metody i konkretnego aplikowania norm w szeroko pojętym zakresie wykonywania władzy rządzenia.

Paolo Gherri, oddając do rąk czytelnika swoją najnowszą monografię, prowokuje we wstępie odniesieniem do intrygującej myśli Karla Poppera, który w Nędzy historycyzmu zachęcał do prostoty i jasności w krytyce określonych teorii, nie wykluczając zastosowania nawet najagresywniejszych metod w ich ocenie. Odwołanie się do refleksji austriackiego filozofa pozwala domniemywać, że całe dzieło autora będzie utrzymane w tonie krytyczno-konstruktywnego poszukiwania alternatywnych i konkurencyjnych rozwiązań problematyki dotychczas podniesionej przez doktrynę, oferując tym samym umotywowaną propozycję własnego stanowiska w kwestii dyscypliny prawa administracyjnego w Kościele łacińskim.

Krytyczny ton znajduje swoje odzwierciedlenie już w pierwszym rozdziale dzieła, w którym autor przekonuje czytelnika o braku konieczności zastosowania analogii lub podobnych odniesień w porównaniu ordynacji kanonicznej z systemami świeckimi w celu określenia pierwotnego charakteru prawności tej pierwszej. Przywołując doświadczenie możliwych i specyficznych wspólnot prawnych (ordynacje statutowe, sportowe, konfesyjne), autor ukazuje wagę, jak również i wartość wzajemnych relacji podmiotowo-instytucjonalnych - zachodzących w ramach jednolitego systemu prawnego - których relatywnie poważna zmiana winna być publicznie uznana, relacyjnie wiążąca i instytucjonalnie sankcjonowana. Zachodzące relacje oraz wspólny do osiągnięcia cel są argumentami pozwalającymi autorowi na postawienie tezy o bezwzględnej autonomii również i prawa kanonicznego, czego bezpośrednią konsekwencją jest możliwość określenia teoretyczno-systematycznej dogmatyki kanonicznego systemu prawnego. 
Zaproponowana optyka rozważań upoważnia autora do nakreślenia szczególnej natury i tożsamości prawa kanonicznego, zwłaszcza w kontekście historycznego kształtowania się jego podstaw i założeń. Autor wielokrotnie podkreśla, że pierwszorzędnym i nadrzędnym zadaniem Kościoła jest głoszenie orędzia ewangelicznego, co - w myśl logiki normatywnej hiszpańskiego teologa Teodora Jiméneza Urresti, że zasada istnienia rzeczy jest jej celem - określa ten sam Kościół jako wspólnotę determinującą konieczne środki (także prawne) do spełnienia tej prymarnej roli. Kościół - dla osiągnięcia publicznych celów, dla których istnieje - jest więc z konieczności instytucją funkcyjną. Tożsamość wspólnotowo-instytucjonalna Kościoła określa zatem publiczny charakter norm prawnych, wykluczając te ustawy, których przedmiotem są relacje wyłącznie międzypodmiotowe. Takie stwierdzenie wynika z analizy kodeksowych norm, czego najwymowniejszym przykładem jest zupełny brak zainteresowania ustawodawcy dobrami materialnymi wiernych (uti singuli), z nadaniem natomiast szczególnego znaczenia tylko tym należącym do kościelnych osób publicznych. Ewidentna strukturalna nieobowiązywalność personalnych prerogatyw wiernych potwierdza zatem tezę o publicznym (instytucjonalnym) charakterze prawnej ordynacji kościelnej, wyrażonym poprzez wolną i wspólną przynależność (pasterzy i wiernych) do orędzia ewangelicznego, jak również wspólne zadanie jego uaktualnienia, ochrony i głoszenia.

W opinii piszącego rozważania podjęte w trzecim rozdziale stanowią najbardziej znaczące novum prezentowanej monografii. Wcześniejsze refleksje miały na celu konsekwentne doporowadzenie czytelnika do krytycznego przyjęcia (lub nie) przesłanek i swoistej logiki - rozumianych jako elementy strukturyzujące prawną ordynację Kościoła - różnych od pozostałych instytucji ludzkich w tym sensie. Punktem centralnym jest zaproponowana perspektywa instytucjonalno-personalistyczna, rozumiana przede wszystkim jako możliwa generalna teoria kanonicznej ordynacji prawnej. Przeświadczenie o tym, że Kościół jest szczególną wspólnotą, mającą własne cele i środki do ich osiągnięcia, wyraża się w przekonaniu, że konstytutywnym zadaniem Kościoła jest ewangeliczne orędzie. Dlatego też autor, stawiając sobie za cel zerwanie z jakąkolwiek analogią do świeckich ordynacji prawnych, uwypukla fakt, że kościelna władza rządzenia spełnia rolę tylko instrumentalną, mając charakter wyłącznie ministerialny i funkcyjny. Bezpośrednimi konsekwencjami zerwania z ideą władzy - pojętej jako panowanie lub zwierzchnictwo - jest fakt jej rozumienia w kluczu odpowiedzialności i/ lub współodpowiedzialności - tak świętych pasterzy, jak i christifidelibus - oraz 
intencyjnego rozeznania władzy. Zaproponowana perspektywa instytucjonalno-personalistyczna wykazuje bezsprzeczną nadrzędność funkcji ministerialnych Kościoła (munera, officia, ministeria) - uskutecznionych przez czynności podmiotów kompetentnych (ministrów) - bez pomijania znaczenia i roli wiernych przyjmujących i głoszących Ewangelię, celebrujących sakramenty, poprzez które upodabniają się do Chrystusa i z pomocą Ducha Świętego dążą do osiągnięcia świętości. W taki sposób dwumian „instytucja-osoba” ukazuje z jednej strony publiczną niezmienność życia według Ewangelii (depozyt wiary i apostolskość Kościoła), z drugiej zaś wskazuje na element zmienny, gdyż przynależny życiu i działaniu każdego ochrzczonego. Jednocześnie autor mocno akcentuje fakt, że element instytucjonalny zaproponowanej teorii formalizuje i czyni konkretnymi zadania oraz funkcje każdego wiernego, nie stawiając go w pozycji nieuniknionej (prawie apriorycznej) z nim konfrontacji.

Czwarty rozdział rozwija longe latequce problematykę tzw. praw podmiotowych wiernych w Kościele. Autor, argumentując swoją pozycję, przekonuje o nieprecyzyjnym odczytaniu przez doktrynę rzeczywistych motywów determinacji słynnych Principia quce (zwłaszcza szóstego i siódmego) - wypracowanych przez I Synod Biskupów w 1967 roku, które w rzeczywistości stawiały sobie za cel zerwanie z arbitralnym działaniem przełożonych na rzecz bezwzględnego podporządkowania każdej czynności prawnej zasadzie legalności. Stąd też w opinii autora zamierzeniem synodu było nie tyle sformułowanie praw podmiotowych i przedmiotowych, ile podkreślenie samej osoby, jej godności, jak również sumienia. Wspominane elementy były pojmowane zatem jako prawdziwe przesłanki służące do prawidłowego sformułowania należytej ochrony wiernych w związku z zapowiedzianą reformą kodeksową.

Właściwe odczytanie przez autora idei magisterium Soboru Watykańskiego II pozwala zauważyć, że tzw. fundamentalne prawa wiernych - prezentowane przez KPK z 1983 roku - wyrażają bardziej wymiar ontologiczny ochrzczonych, nie stanowiąc zaś tego, co doktryna świecka określa mianem ścisłej prawności w definiowaniu suum cuique. Dodatkowo, należy wziąć pod uwagę fakt ograniczenia wiernych - w wykonywaniu swych „praw” - w konstytutywnej zasadzie kościelnej komunii, jak również zależności od hierarchicznej struktury Kościoła, co w konsekwencji uprawnia do określenia prerogatyw wiernych w kategoriach libertas (wolność, uprawnienie, swoboda), nie zaś ius/iura, sic et simpliciter. Stanowisko autora nie neguje jednak faktu bezsprzecznego istnienia personalnych prerogatyw - zagwarantowanych przez ustawodawcę kodeksowego - oraz sądowej obrony 
korzystnych sytuacji prawnych podmiotów, zgodnie z dyspozycją kan. 1400 § $11^{\circ}$. Powyższe spojrzenie pozwala także na stwierdzenie, że w przypadku prawnej ochrony personalnych prerogatyw prawo kanoniczne chroni de facto personalny status ochrzczonego, mając szczególny wzgląd na personalne więzy jednostki (vincola), od których zależy możliwość relatywnie poważnej modyfikacji własnej pozycji systemowej.

Na kanwie rozważań o tzw. iura subiectiva, autor słusznie proponuje dogmatyczne rozróżnienie między aktem/czynem bezprawnym (contra legem) a tym nieprawowitym (infra legem). Właściwe wyodrębnienie tych dwóch różnych co do przesłanek i efektów czynności staje się istotne, ponieważ akty bezprawne łamią bezpośrednio przewidziane i wprost chronione przez ordynację prawa wiernych, zaś te dokonane infra legem - mimo swej ważności - pozwalają poszkodowanemu na sformułowanie remonstrancji i - w przypadku jej nieskuteczności - rekursu skierowanego do hierarchicznie wyższej od autora aktu władzy. Autor, contra communem opinionem Magistrorum, wykazuje specyficzne źródło kościelnej ochrony podmiotów. Nie chodzi o obronę tzw. praw podmiotowych (w znaczeniu dóbr/ interesów osób prywatnych), a raczej o instytucjonalne wykluczenie jakiejkolwiek formy arbitralności, urzeczywistnianej poprzez czynności administracyjne formujące proporcjonalne do przypadku drogi proceduralne.

Idea ministerialnej natury Kościoła - określona przez autora w piątym rozdziale monografii - staje się niezbędna do pełnego rozumienia statusu epistemologicznego dyscypliny „kanoniczne prawo administracyjne” (rozdział szósty). Bezpośrednim odniesieniem autora jest oczywiście doktryna ostatniego Soboru, który w sposób elokwentny nadał każdemu z wiernych - na swój sposób i zgodnie z własną każdego prawnokanoniczną pozycją - obowiązek czynnego uczestnictwa w potrójnej misji Chrystusa. Mając na uwadze wcześniejsze wnioski odnośnie do rozumienia Kościoła jako wspólnoty funkcyjnej (powołanej do głoszenia Ewangelii), w której elementami wiążącymi są relacje i poszczególne role wiernych względem elementów „statycznych” (depozyt wiary i Tradycja), Autor podkreśla ministerialny charakter Kościoła, wezwanego do zwyczajnej posługi każdemu ochrzczonemu, tj. adresatowi i protagoniście jednakowej misji Kościoła.

Przywołana raz jeszcze idea/wizja Kościoła - zamknięta w dwumianie instytucja -osoba (dobro wspólne/publiczne i indywidualny pożytek) - upoważnia autora do zajęcia krytyczno-konstruktywnego stanowiska w ciągle otwartej doktrynalnej dyskusji na temat źródła (źródeł) kościelnej władzy rządzenia. Po raz kolejny autor odwołuje się do myśli Teodora Jiméneza Urresti, konstruktora teorii prawnej 
„władzy domyślnej”, według której każdy, kto zleca podmiotowi pełne i skuteczne osiągnięcia zamierzonych celów, powierza równocześnie, w sposób domyślny, wszystkie konieczne do tego środki. Idea potestas a munere, zdaniem autora, kładzie kres poważnym trudnościom doktrynalnym w określeniu pochodzenia władzy rządzenia, jak również zamyka drogę jakimkolwiek wątpliwościom - możliwym do sformułowania w przyszłości.

Przedostatni - szósty - rozdział porusza problematykę autonomicznego statusu epistemologicznego kościelnego prawa administracyjnego, oferując jednocześnie właściwe studium akademickie materii, spójne pod względem zaproponowanego „systemu”. Autor, analizując dzieła już istniejące, denuncjuje brak kompleksowego spojrzenia na materię, nakreślając jednocześnie własne propozycje jako potencjalną możliwość rozumienia kościelnej ordynacji zakorzenionej w szeroko pojętej Tradycji i magisterium Soboru Watykańskiego II, w myśl zasady a Concilio ad Codicem. Przywołane argumenty pozwalają autorowi zdefiniować kanoniczne prawo administracyjne jako adekwatną i instrumentalną odpowiedź Kościoła na konieczność jego budowania i wzrostu, czyniąc jednocześnie wspomniany zbiór norm pierwszym i najskuteczniejszym instytucjonalnym narzędziem zachowania wzajemnej komunii. Co więcej, przyjęta eklezjologiczna i pastoralna perspektywa oglądu kościelnego prawa administracyjnego uprawnia włoskiego kanonistę do zdefiniowania prawa jako zbioru norm regulujących skuteczną legalną działalność wiernych, uwzględniając ich prawno-kanoniczną publiczną pozycję (status, zadania, funkcje). Z punktu widzenia zaś akademickiego, w maksymalnej syntezie, autor definiuje prawo administracyjne jako systematyczną teorię skuteczności prawnego kościelnego działania.

Ostatni - siódmy - rozdział pracy poświęcony jest w całości idei wyjątkowej specyfiki kanonicznego prawa administracyjnego. Paolo Gherri udowadnia, że autonomia systemu - a przede wszystkim zasadne fundamenty jego istnienia - nie jest uzależniona od stałego odwoływania się do modeli administracyjnych wypracowanych przez świeckie ordynacje prawne. Udowodnienie oryginalności systemowych założeń kościelnego prawa administracyjnego upoważnia autora nie tyle do systematycznej ekspozycji zagadnień materii oraz rzetelnego określenia jej metod, ile raczej do dokonania uargumentowanego dyskursu o charakterze fundacyjnym, możliwym - jeśli nie koniecznym - do sukcesywnego pogłębienia doktrynalnego prawa administracyjnego. Dodatkowo autor, z właściwą sobie sumiennością i starannością naukową, wykazuje niekompatybilność systemów administracyjnych Kościoła i państw, ukazując, 
że aktualizacja władzy rządzenia przez kompetentne podmioty kościelne nie znajduje żadnej analogii do cywilnych public services. Wynika to z radykalnie odmiennych przesłanek - typowych dla prawnej ordynacji Kościoła i państw - jak i celów, stawianych sobie przez władzę wykonawczą w Kościele, którego rozumienie, z punktu widzenia podjętych badań, nie może być zredukowane do pojęcia „publiczna administracja kościelna”.

Jednakże analiza i krytyczne porównanie współczesnych systemów do ordynacji kanonicznej czyni możliwym nowatorskie spojrzenie na prawodawstwo Unii Europejskiej pod kątem społeczno-funkcyjnym i ukazanie zaistniałych podobieństw do kościelnych założeń teorii prawa administracyjnego. W tym względzie autor sygnalizuje, że nie jest istotna natura Unii, lecz elementami szczególnego zainteresowania naukowca jest jej sposób działania, dynamika i funkcjonalność (np. wiodąca rola działalności ustawodawczej państw członkowskich nad organem centralnym; w miejsce praw podmiotowych - tzw. libertas; urzędy i organy unijne ustanowione ratione materice i tym podobne do dykasteriów rzymskich, funkcyjnych par excellence).

Monografia ks. Paolo Gherriego wpisuje się zatem w brakujące krytyczne spojrzenie nie tylko na kościelne prawo administracyjne, ale także na całą ordynację kanoniczną. Wielka erudycja autora, nie tylko teologiczno-kanoniczna, lecz również pochodząca z obszaru nauk filozoficznych i społecznych (nie tylko włoskojęzycznych), pozwala na formułowanie rzetelnych i naukowych odpowiedzi na pytania o publiczną administrację w Kościele, o istnienie kościelnego prawa administracyjnego czy wręcz o funkcjonowanie wymiaru kościelnej sprawiedliwości administracyjnej; interpelacja, na którą autor odpowiada w odmienny niż większość doktryny sposób. Przyjmując odmienne przesłanki, określając ideę Kościoła i jego dynamikę działania w kluczu instytucjonalno-personalistycznym, podkreślając ministerialność jako istotę kościelnego prawa i fundamentalne znaczenie relacji zachodzących między wiernymi a kościelną władzą, autor formułuje nowatorskie wnioski.

Z całą pewnością należy stwierdzić, że niniejsza monografia nie stanowi typowo akademickiego podręcznika, a raczej jest rzetelnym przyczynkiem naukowym, wymagającym starannej bazy pojęciowej w celu zbudowania osobistego odniesienia i osobistej krytycznej pozycji względem niektórych - kontrowersyjnych - propozycji systemowych sugerowanych przez autora.

W opinii piszącego dość znacznym mankamentem dzieła jest nadmiar wtrąceń wprowadzonych w główny korpus tekstu za pomocą nawiasów, kursyw, nadmiaru 
cudzysłowu, co świadczy o stosowaniu przez autora specyficznego „kodu” językowego, który dla wielu może stanowić pokaźną przeszkodę w płynnym przechodzeniu z jednej kwestii do drugiej. Mimo wspomnianego braku - być może tylko subiektywnego - monografia jest innowacyjnym, nieszablonowym, godnym polecenia dziełem, pozwalającym na odmienne spojrzenie na kanonistykę, a w sposób szczególny na kościelne prawo administracyjne.

Przemysław Michowicz OFMConv 